\title{
Research into the Educational Management Mechanism and System Management Innovation at Colleges and Universities
}

\author{
Min Wei \\ Library, Jilin Agricultural University, Changchun, 130118 \\ 434975141@qq.com
}

Keywords: Higher education; Management mechanism; System management; Innovation

\begin{abstract}
Innovation is an inexhaustible motive force for the development of national and social progress. Similarly, for the education management of colleges and universities, innovation is also essential. In today's rapidly changing times, students' active thinking, personality, the traditional "tube, pressure" mandatory management mode does not adapt the development of the college students, limiting the student's thinking innovation, innovation for university management system and mechanism of education, respect students' personality, humane management, to create a relaxed atmosphere of management. To mobilize the initiative and creativity of college students.
\end{abstract}

\section{Introduction}

The management of ideological and political education management in colleges and universities is divided into teaching, administration and management of students, the main object is the teachers and students, while the colleges and universities in recent years in the field of management system reform, but still have little effect, frequent problems, students and teachers are still subject to the rigid constraints of the system, limiting the potential. In order to meet the needs of economic and social development of science and technology and the cultivation of high-quality talents, the need for innovation of university management system and mechanism, to ensure the quality of teaching, respect the subjectivity of students, develop students' innovative spirit, and constantly improve the management system, improve the management level.

\section{Current Status of Education Management System at Colleges and Universities}

At present, colleges and universities in China are constantly reforming the credit system, embodying the subjectivity of students, which is conducive to five full play to students' personality. However, there is no unified educational management mode in China's colleges and universities while different colleges and universities have different manpower, materials and financial resources, so the corresponding management systems are also diversified. In this way, there are many problems in management systems, mainly including the following three aspects:

Management Systems and Mechanisms at Colleges and Universities Are not Flexible. Although many universities are active in innovating management, due to the particularity of the system, the reform lags behind. For example, it is very difficult to modify teaching technology, school management and education evaluation system with a lack of flexibility without attaching importance to the initiative of individual students. Although in the protection of the system and mechanism, the work of colleges and universities can be carried out smoothly, but too mechanical must not be able to mobilize the creativity of teachers and students. For example, the current credit system in Colleges and universities in the implementation of the credit system on the one hand, whether the teacher resources sharing and a variety of hardware and software resources, teachers face the problem of imbalance, on the other hand, the implementation of the credit system will break the traditional fixed length of schooling, restrictions and diplomas issued, the traditional classroom management will is broken, so the management system of colleges and universities the lack of flexibility will inevitably lead to the credit system is difficult to operate.

Education Administration. Because the tradition of running a school in China is by the government, the government's longitudinal restraint mechanism is more obvious, and the trend of 
educational administration appears. In the modern sense, the university is actually the extension of the function of the government; government intervention to make the management of colleges and universities is not independent. Weakening and the government and the society, is not conducive to the university according to their own independent management training to meet the needs of the labor market. The condition of running a school, the support of the resources and the direction of running a school are all affected by the government's intervention and lack of institutional innovation. In addition, the administrative system is restricted by the lack of liquidity management personnel, personnel mechanism fixed, many in the teaching, scientific research does not contribute to the people still enjoy a good salary and allowance, a waste of educational resources, the management system of many more personnel than work available, affect the higher education system reform, colleges and universities need to grasp their own direction, get rid of the administrative intervention system, change the administrative management mode and level, this work also needs the support of the state.

Insufficient Protection of Students' Interests and Rights. In the whole process of university education, rights and obligations are parallel, but in most colleges and universities, colleges and universities have the right to manage, only to listen to the students, to fulfill their obligations, rarely enjoy the right to. In order to manage the university has no clear penalties in punishing students, the object of student complaints is often punished department personnel, this will inevitably lead to the complaint nowhere, affect students' appeal rights and supervision functions. Students are the future of the country, is supposed to enjoy the highest rights and interests, the university is a service, all systems, mechanisms and the purpose of education management should be for students. Students should be paid enough attention to the protection of the rights and interests of students, colleges and universities should promptly balance the interests of all parties, innovation and improve the management system, the maintenance of the interests of students, promote their own progress.

\section{Strategies of Innovation Education Management Mechanism and System Management at Colleges and Universities}

Improve Education Management System at Colleges and Universities. First, establish college education management policies based on independent running a school. Colleges and universities to establish a relaxed policy environment in order to ensure the independence of the development of colleges and universities, to avoid the administrative trend of management. The mastery of independent academic power can really play the academic power, at the same time, higher education management and the corresponding management institutions need to change the role of conversion, the command style management of students, student services, guidance. In addition, colleges and universities should allow teachers to master the allocation of educational resources, flexible grasp of all aspects of information.

Second, education management policy should enhance humanistic concern. Because college students' personal development is associate with their employment and future life in the society with a strong utilitarianism tendency, neglecting that teachers' responsibility is to cultivate persons with mental state and perfect personality. It emphasizes that the key of attending colleges is the practical value, which is actually a misleading. Therefore, colleges and universities should make their management systems more flexible, and embody the value of people and their dominating status in management, enhance humanistic care and fully tap the potential of students.

Third, college's education management policy should insist on the concept of harmonious development. Colleges' management system should start from both students and teachers as a whole to make every student and teacher benefit. Meanwhile, teachers and students should make progress together and get along harmoniously. Colleges and universities should not just cultivate the same type of students and the main purpose is not cultivating standard talents. University education management system to reflect the values of people, so that students in their own creation of the world to know their own. Teachers and students should respect each other, adhere to the needs of students as the focus, rather than simply ask students to obey.

Innovate the Guarantee Mechanism for College Educational Management System. First, 
change the mechanism of choosing college education management system. In the process of university management, the thought of planning economy and centralization is permeated. University education direction, education system, resource allocation and other aspects are affected by the country's development. The education management system of higher education is restricted by the relevant regulations of the government department. Universities should start from their own specific circumstances continue to innovate management mechanism, to establish compliance with social development closely followed by the era of management mechanism.

Second, improve incentive mechanism at colleges. The establishment of a reasonable incentive mechanism in Colleges and universities can stimulate the enthusiasm of teachers, to avoid the different interests of being suppressed. At present, a lot of institutions in colleges and universities limit the need for people to pursue legitimate interests. Therefore, the education management system should be established on the basis of multiple interests, and constantly improve the incentive mechanism.

Third, improve the subjective mechanism of college education management. Under the limit of traditional college education management, students' initiative in learning is poor without any freedom. They learn whatever the school arrange, neglecting their personal interests and hobbies, thus college students resist college management system and have the negative mentality. Therefore, the college education management system should improve the main mechanism, adhere to the students as the center, gradually balance between higher education management and free play management, management system for the students' norm function on the one hand, on the other hand and not obliterate the personality of students, improve the openness of the system, let the students choose learning content.

Establish the College Education Management System of "Ruling the School by Professors". First, change concepts. "Ruling the school by professors" does not mean to let professors and experts manage various matters and students at the school, which is just the literal understanding of it. Actually, it means that professors and experts should be engaged in formulating the college systems, express their own opinions and provide reference for the formulation of college system from different perspectives so as to indirectly manage the school. Implementing system and decision management are two different concepts. We should grasp the limit of "ruling the school by professors" and make professors appropriately use their rights.

Secondly, improve rules and regulations. "Ruling the school by professors" should not just remain on words, but should be implemented according to relevant laws and regulations. To innovate college management system can provide corresponding carrier for it. We can establish the Professor Committee Department in the Department, to contribute to the university academic staff can make management decisions, at the same time, in the school board of education, the academic degree evaluation committee and other groups, can increase the number of professors, avoid administrative factors interference. In addition, gradually improve the members Professor related systems and regulations, to ensure that the professors and democratic norms. Universities and academic related posts should be selected for those who have both academic ability and management experience, to ensure that the educational management system is reasonable.

Innovate Education Quality Assessment System. The evaluation system of scientific innovation can effectively ensure the smooth implementation of the education management system and the system of higher education. Therefore, in the evaluation system, the university should strive to reform, to ensure the quality of education in Colleges and universities. First, colleges and universities should establish a comprehensive evaluation system of the goal. Scientific and comprehensive evaluation system and system have an important role in the operation of the full range of incentive mechanism, the formation of a comprehensive management, all-round teaching situation. The evaluation system of innovation goal education mainly has the supervision and guidance evaluation, the university management evaluation, the education development appraisal and the student development evaluation and so on. Goal evaluation is not simply to achieve teaching goals, it pays more attention to the education process, pay attention to the continuity of education, extensive, is based on the physical and mental development of college students and 
teachers teaching situation assessment. The main evaluation aspects are, teaching evaluation, supervision and guidance evaluation, evaluation of the management of colleges and universities social evaluation. Second, improve the assessment mechanism for students' evaluation of students, including students' physical and mental health, the student's final and usually grades, students' personal interests and their ideological and political quality. The evaluation mechanism for students to be fair and reasonable, each student is equal, have their own expertise, academic performance cannot be used as the only evaluation criteria. Third, the establishment of the evaluation system of the teaching situation of teachers. Teachers' scientific and rational evaluation can improve the enthusiasm of teachers' work and dedication. The focus of the evaluation of teachers in Colleges and universities, the evaluation of the appropriateness of the direct impact on the development of teachers and their attitudes to students. The evaluation of teachers should be carried out from the moral, diligence, ability, and can also be used as a reference for the evaluation of the teacher.

\section{Conclusions}

In short, in the new period of reform and innovation, the development of colleges and universities should adhere to the advanced and innovative trend, with the development of the times, disadvantages of colleges and universities to change the traditional education management mechanism and system, from the perspective of teachers and students, and continuously improve the effectiveness of Education Management system, ensure the teaching of higher education work smoothly.

\section{References}

[1] Wei Qiaoyan, Li Ruigui. Discussion of Humanistic Issues in Teaching Management System at Colleges and Universities [J]. Research into Heilongjiang Higher Education. 2009(6):32.

[2] Li Ruigui. Analysis of the Lack of Internal Factors in Teaching Management System at Colleges and Universities [J]. Textile Education, 2010(1):5.

[3] Wang Linyi, Yu Qiao'e. Outlook of Scientific Development and Humanistic Education at Colleges and Universities [J]. Teaching Knowledge and Cultivating Talents (higher education forum), 2012(1):58-59.

[4] Gao Yannan. Exploration and Practice of Teaching Management System of Colleges and Universities with the Humanistic Concept [J]. Science Information, 2012(04):217.

[5] Wei Min. Research into College Teaching Management from the Perspective of Humanistic Management [J]. Seaside Enterprises and Science, 2011(06):23-24.

[6] Yang Aijun. Exploration into Establishing Higher Education Teaching Management System based on Humanistic Concept [J]. Education and Career, 2011(29):165-166.

[7] Zhao Zepeng. College Education Management in the Concept of "Innovative Education" [J]. Research into Continued Education, 2010,(5) .

[8] Guo Wujun. Reflection of Innovation College Education Management [J]. China's Adult Education, 2007, (3) .

[9] Chen Congzhi. Reflection of College Education Management Innovation in the New Situation [J]. Journal of Henan University of Technology (social science edition), 2005, (2) .

[10]He Ruoquan. College Education Concept under the Guidance of People-Oriented Outlook of Scientific Development [J]. Journal of Suzhou University of Science and Technology (social science edition), 2006(4): 119.

[11] Ma Qiaoxia. Reflection on the Humanistic Management of Higher Education [J]. Journal of Shaanxi Normal University (philosophy and social science edition), 004(S1):131-132. 
[12]Chen Kuxi. Current Situation and Features of the British Education Administration System [A]. Compiled by Comparison Education Association of the Republic of China: Research into Comparison of Education Administration [C] Taipei: printed by Taiwan bookstore: 143. 